\title{
Ulisses no carro do sol
}

Ulysses in the sun's car

Daniel Vecchio Alves*

danielvecchioalves@hotmail.com

Universidade Estadual de Campinas

RESUMO: Neste artigo, a epopeia homérica será a fonte escolhida para demonstrar um conjunto de saberes estabelecido anteriormente aos naturalistas jônicos. Em nossa hipótese de leitura, a épica de Homero já apresenta um inicial posicionamento naturalista, a começar pelo fato de suas obras constituírem, a partir da experiência de morte, um elogio à própria vida. E para demonstrar esse jogo de antíteses entre as duas experiências, veremos que, na épica homérica, a presença do relato de viagem tem o propósito de registrar o real exclusivamente apreendido pelos sentidos humanos, mesmo nas cenas mais subjetivas que envolvem lugares infernais e seres lendários. Não afirmaremos tal característica a ponto de transformarmos Homero num empírico, mas trata-se de uma primeira alternativa frente o passado maravilhoso evocado pelos aedos da tradição.

PALAVRAS-CHAVE: Épica. Memória. Sentido. Olhar. Viagem.

ABSTRACT: In this article, the Homeric epic will be the chosen source to demonstrate a set of knowledges previously established to the lonian naturalists. In our reading hypothesis, the epic of Homer already presents an initial naturalistic position, starting with the fact that his works constitute, from the experience of death, a compliment to life. And to demonstrate this set of antitheses between the two experiences, we will see that in the Homeric epic the presence of travel report is meant to record the real, exclusively seized by the human senses, even in the most subjective scenes involving infernal places and legendary beings. We will not assert such characteristic to the point of turning Homer into an empiric, but it is really a first alternative to the wonderful past evoked by the innumerable prophets.

KEYWORDS: Epic. Memory. Sense. Vision. Journey.

\footnotetext{
" Mestre em Estudos Literários pela Universidade Federal de Viçosa (UFV) e doutorando em História Cultural pela Universidade Estadual de Campinas. É bolsista CNPq.
} 


\section{Introdução}

É com certa insistência que historiadores da filosofia apresentam o surgimento do racionalismo grego somente a partir do naturalismo jônico, origem complementada com breves referências a um suposto pensamento helênico anterior destituído de lógos. Trata-se de um enquadramento bastante arriscado, visto que compromete o sentido mais profundo do racionalismo proveniente de períodos préarcaicos da Grécia antiga (antes de 8.000 a.C.), em que o canto, a imagem da morte e a noção de destino possuem extrema importância, especialmente para o desenvolvimento da cosmologia, da comunicação e da arte poética.

Parte do lógos da mentalidade desse período se centra na imagem da vida no futuro e no além, preocupação manifestada por várias tradições como os cultos a Apólo, Elêusis, Dionísio e Orfeu. Nessas tradições está em jogo uma meditação sobre o ser humano e seu destino, sobretudo um destino posterior à existência terrena. Tal significação da morte provoca uma forte dialética com a própria imagem da vida, dialética na qual encontramos os primeiros dados da racionalidade grega, constituída pela experiência no além e sua imanente tentativa de compreensão do funcionamento cósmico da vida.

Nesse contexto, a epopeia homérica será a fonte escolhida para demonstrarmos tal gama de conhecimento existente anteriormente aos jônicos. Em nossa hipótese de leitura, a épica de Homero já apresenta um inicial posicionamento naturalista, a começar pelo fato de suas obras constituírem, a partir da experiência de morte, um elogio à própria vida. Para demonstrar esse jogo de antíteses entre as duas experiências, veremos que, na épica homérica, a presença do relato tem o propósito de registrar o real exclusivamente apreendido pelos sentidos humanos, mesmo nas cenas mais subjetivas envolvendo lugares infernais e seres lendários.

Não afirmaremos tal característica a ponto de transformarmos Homero num empírico, mas trata-se de uma primeira alternativa frente o passado maravilhoso evocado pelos aedos da tradição, tendo por base o testemunho dos heróis. Desse modo, para a efetivação de um relato sensorial do mundo micênico do século XII a.C. na tessitura épica da llíada e da Odisséia, observaremos que Homero executa "uma rudimentar historização do sobrenatural" (SCHUTZER, 1956, p. 383). Portanto, em nossa leitura, sua poética apresenta uma incipiente construção do testemunho 
histórico, tendo por base uma descrição sensorial das ações passadas, técnica que será aperfeiçoada bem futuramente pelos cronistas.

\section{Espelho de Homero}

Muitos continuam a se fundamentar nas afirmações do historiador Moses Finley, de que "nem Homero nem Hesíodo manifestaram o mínimo interesse pela história [...]. Estes poetas davam pouca atenção ao factos do passado ou presentes e, no caso de Homero, nem sequer se explora as consequências dos acontecimentos" (FINLEY, 1988, p. 26). Entretanto, não podemos afirmar convictamente que "Homero não dá outras indicações acerca dos guerreiros que combateram em Tróia além do: ‘Era uma vez' [...]” (FINLEY, 1988, p. 26).

Finley (1988) foi radical em relação ao não reconhecimento da reflexão memorialística já contida na épica de Homero, especialmente na Odisséia, pois se Homero soube aproveitar bem alguma coisa em relação a esse tema, essa coisa é menos a história que o historiador enquanto sujeito que vive, lembra e escreve. A arte de representar a história em Homero, longe de se reduzir aos catálogos das naus embarcadas e dos guerreiros, liga-se às complexidades de penetrar nos problemas universais da memória, como alerta a mãe de Ulisses: "Apressa-te, / regressa à luz o quanto antes, guarda na memória o / que viste para que possas transmiti-lo a tua mulher" (HOMERO, Od., XI, 222-224). Não podemos negar toda a realidade das ações narradas, para ver em Homero apenas imaginação poética, mitos ou personagens sem consistência histórica. Isso nos parece ir longe demais.

Com seus cantos, Homero nos convida à Grécia pré-arcaica sob uma espécie de regime feudal, território fragmentado onde reinavam os soberanos da llíada e da Odisséia. Claro está que, muitas vezes, existe certa individualização dos fatos que se sobrepõe a outras causas mais verossímeis, por isso o rapto amoroso de Helena para explicar os motivos da guerra de Tróia, em detrimento da importância da luta comercial pelo ponto Euxino: "[Helena] Desgraçou-nos a nós todos" (HOMERO, Od., XXIII, 224), afirmava Penélope. Trata-se de uma disposição microcósmica que encontramos também quando o narrador homérico nos demonstra atenção às cenas de guerra, como naquela referente a um capacete que, no meio da batalha, "soa bruscamente, ao cair por terra", e que "voa no ar, e vai cair por terra, onde um dos 
aqueus, / ao combater, o agarra, enquanto lhe rola entre as pernas" (HOMERO, II., XIII, 578-579).

Enquanto Moses Finley, em O Mundo de Ulisses (1988), se concentra apenas em realizar um verdadeiro catálogo de erros históricos cometidos por Homero, forçando o desencontro de suas descrições com a cultura material descoberta ao longo da modernidade, Robert Aubreton (1968), em contrapartida, balanceia acertos e erros, assinalando mais a série de acordos e cuidados históricos realizados pelo poeta. Para Finley, o principal erro de Homero está situado no catálogo das naus da llíada, em que o poeta enumera 1186 navios, resultando em mais de 60.000 homens, número que, segundo Finley, "[...] é tão digno de fé como os 400.000 Sarracenos da Canção de Roland. O mundo de Ulisses era pequeno em população. [...] a extensão demográfica de cada comunidade não devia exceder quatro algarismos e amiúde mesmo três [...]" (FINLEY, 1988, p. 49).

Porém, nem toda crítica à série de equívocos homéricos se sustenta. Para Aubreton (1968), por exemplo, muitos são os pormenores de suas épicas que correspondem às descobertas arqueológicas, como no caso da couraça que os aqueus e troianos utilizavam, objeto descoberto em várias regiões gregas, presente numa passagem da Odisséia (XIX, 225-226): "O divino Odisseu trazia uma capa de / lã, purpúrea, dupla, presa por um broche áureo / de duplo encaixe, uma dedálica obra de arte". Além disso, para Aubreton "o megaron do palácio de Ulisses, em Ítaca, devia parecer-se com o descoberto em Micenas, assim como [...] o palácio de Nestor" (AUBRETON, 1968, p. 110-111).

Diante dessas constatações, temos a representação incipiente da memória no entorno da civilização micênica, construção que margeia as fronteiras entre o empírico e o divino. Trata-se da principal marca de autoria de Homero a ser explorada aqui: o surgimento dessa espécie de "fenômenos acabados, uniformemente iluminados, definidos temporal e espacialmente, ligados entre si, sem interstícios, num primeiro plano" (AUERBACH, 2009, p. 9). No entanto, concordamos apenas parcialmente com Auerbach, ao afirmar que a épica homérica tende mais à ficção por desenvolver-se de maneira "excessivamente linear" e que "tudo o que correr transversalmente, [...] é apagado" (AUERBACH, 2009, p. 16).

É certo que os testemunhos mais contemporâneos transcorrem de modo muito menos uniforme e mais cheio de contradições, e "a lenda ordena o assunto de modo unívoco e decidido, [...] de modo que este não pode intervir de maneira 
perturbadora; só conhece homens univocamente fixados [...]" (AUERBACH, 2009, p. 16). Todavia, o que pretendemos esclarecer aqui é que, com essa marca realista, a obra épica de Homero nos serve de embrião para se pensar a incipiente representação do testemunho histórico, com rica e embasada caracterização sensorial. Defenderemos, portanto, que a leitura de Auerbach sobre a linearização ficcional dos eventos na épica é coerente, porém não perturba a experiência do relato histórico em Homero, que se aproveita dos enredos poéticos para firmar uma experiência perceptiva do testemunho narrado.

\section{Uma epopeia contra o esquecimento}

Inspirado pela musa, o aedo celebra os deuses e os grandes feitos dos heróis. Geralmente convidado para um banquete, espera-se dele que proporcione aos convivas prazer e esquecimento das tristezas presentes. Por meio de seu canto evocativo, aquele que viveu gloriosamente e que teve igualmente uma morte gloriosa recebe, em troca, um canto imortal. Desse modo, podemos considerar o aedo como o distribuidor de glórias, o ordenador da memória alegórica de um dado grupo, transmissor de um passado de ações heróicas: "Quem pisa a superfície terrestre / deve reverência aos cantores, pois o que sabem vem / da Musa. Ela ampara os versos dos aedos" (HOMERO, Od., VIII, 479-481).

Ao investigarmos as implicações da tradição dos aedos na llíada e na Odisséia, nos deparamos com o fato de Homero surgir como seu herdeiro e reorganizador. Os templos ainda deviam servir ao poeta de verdadeiros repositórios memoriais, conservando, mais do que qualquer outro lugar, a lembrança de deuses e guerreiros. Todavia, o que pretendemos demonstrar aqui é que em Homero há uma incipiente modificação na forma de conduzir o passado, o que parece representar um primeiro esforço de reorganização dessas memórias.

Em suas épicas já podemos identificar certo deslumbramento pela clareza das explicações sobre o mundo dos reis e heróis micênicos. Homero encontra no relato de guerra e de sobrevivência uma íntima conexão com esse mundo exterior tanto que os aedos homéricos, como Fêmio (em Ítaca) e Demódoco (na Esquéria), cantam as memórias dos heróis, deixando de evocar as ações antepassadas conforme a tradição, mas cedendo seu canto ao narrador da épica, que se compromete em parafrasear o conteúdo dos cantos (grifo nosso): "Detalhou o saque 
dos que saltaram em / torrente do cavalo, esvaziando o esconderijo. Cantou / como depredaram a soberba cidade. Destacou / os feitos de Odisseu contra o palácio de Deífobo; / acompanhado de Menelau, parecia Ares. Sublinhou o / ímpeto guerreiro que levou o bravo Odisseu à vitória / [...]. / Em síntese, o que o aedo cantou foi isso" (HOMERO, Od., VIII, 514-527).

Sendo assim, o aedo é destituído de sua insígnia sacra para expandir a prática do canto entre guerreiros e aventureiros, que, por sua vez, passam a recitar o próprio passado vivido. Nesse sentido, o aedo homérico cede lugar a quem quisesse nos relatar suas aventuras. Por isso, a descrição das ações passadas em Homero é reduzida ao campo sensorial dos heróis que protagonizaram e testemunharam feitos: "Vamos! Quero que fales sem rodeios. / Conta-nos por onde andaste, terras e gente que / conheceste, cidades populosas que tenhas visitado" (HOMERO, Od., VIII, 572-574).

O aedo homérico vive, portanto, numa era em que o canto é dependente da interferência de seu próprio presente. Porém, o aedo, no geral, sempre será aquele que vê o que, todavia, nunca viu e se lembra do que ele, a bem dizer, jamais conheceu. Por isso, com a presença de Ulisses na corte dos Feáces, seu canto evocatório é substituído pelo testemunho do guerreiro, que desabafa: "Meus cuidados, os gemidos que não consigo abafar / no peito, inquietam-me agora Isso agrava minha dor. / Nem sei por onde começar. Deixo para o fim o quê?" (HOMERO, Od., IX, 12-15). Nesse processo de reorganização da tradição poética dos aedos, Homero reposiciona como centro da ação não a ira de Aquiles ou a errância de Ulisses, mas o próprio objeto cantado, passando a organizá-lo por um mythos, conceito definido por Aristóteles como espécie de sincronização dos fatos. A diferença aqui é que, no capítulo vinte e três da Poética, Aristóteles opunha o mythos épico e trágico à história (ARISTÓTELES, 2004). Já em Homero essa tese aristotélica é retorquida:

[...] a história una ou "universal", aquela que eu escrevo, possui as mesmas características do mythos (segundo a definição que lhe dá Aristóteles): ela forma um todo (holon), isso quer dizer em termos aristotélicos que ela tende a um fim único (telos), que ela tem um começo, um meio e um fim, [...]. Ora, isso não é problema, pois o ideal de historiador é, para Políbio, não Demódoco, mas Ulisses, o homem da experiência, aquele que suportou e viu com seus próprios olhos (HARTOG, 2000, p.11-18). 
Logo, não devemos considerar o objeto cantado por Homero como matéria transmitida pela evocação às Musas da memória, interpretação similar à tese de Eric Havelock, que, motivado pelos estudos Milmam Parry, considerava os poemas homéricos apenas transcrições de um código de cultura, reduzindo o discurso poetizado a uma "estocagem de informação e ritos sacros", "documentação oral de uma cultura não-letrada" (HAVELOCK, 1996).

É preciso perceber, com isso, que a composição das épicas homéricas não se dá mais do mesmo modo como ocorria nos cantos orais dos aedos tradicionais. Temos que salientar neste ponto que Homero, ao escrever seus cantos sobre o ciclo troiano, não se submete ao mesmo exercício espiritual da tradição oral épica. Com Homero, o espírito histórico-filosófico apoderou-se da poesia, sinal inequívoco de que esse espírito, aliado à arte da linguagem, começa a tornar-se uma força educativa em seu tempo, impulso que levou a filosofia e a história a surgirem e desdobrarem-se da forma poética a partir de suas apropriações universais da ação humana: "Dissabores se amontoaram. Que voz / perecível saberia narrá-lo todos? Ainda que / resolvesses permanecer por cinco ou seis anos, / não conhecerias todas as privações dos aqueus. / Exausto retornarias à terra em que nasceste" (HOMERO, Od., III, 109-117).

Além de Ulisses, há muitos outros personagens cantores-narradores pelas épicas homéricas que testemunham e conservam a memória de ações passadas. Ouve-se, por exemplo, Aquiles cantando as glórias de seus antepassados: "[Aquiles] Tangia uma lira/ - cordas presas em trave de prata - artefato dedáleo, que o enlevava, do espólio e Eecião, e a cujos sons cantava gestas de heróis" (HOMERO, II., IX, 187-190). Contudo, no caso da llíada, ainda encontramos a apreensão de uma perspectiva temporal distanciada entre a ação do poema e o registro do passado. Como afirmou Jonas Grethlein, ao tratar do que chamou de "passado embutido" nos poemas da llíada, afirma "a inferioridade dos heróis em comparação com seus ancestrais [...]" (GRETHLEIN, 2010, p. 131-132).

Exemplo dessa relação entre passado e presente distanciados nos é fornecido por uma fala de Heitor, no canto VII dessa mesma épica, momento em que o herói reflete sobre o futuro sinal de sua glória: "Um dia / no futuro, em sua nau polirreme sulcando / as ondas do mar cor-de-vinho, um navegante / dirá: 'Vejam, é a tumba de um herói de antanho, um valente; matou-o Héctor fulgurante.' / Dirá. E minha glória viverá perene" (HOMERO, II., VII, 86-91). Nessa distanciação temporal, 
os seres humanos não teriam força suficiente para realizar algo extraordinário, quebrando essa barreira temporal.

Se na llíada é clara a preocupação dos heróis em se tornarem memoráveis pelo canto de outras eras, na Odisséia, esse distanciamento temporal é desfeito em prol da experiência do testemunho, a exemplo de Ulisses, testemunha e cantor de seus próprios feitos. Ulisses rememora e reavalia sua trajetória pregressa, revelando assim, segundo o rei Alcínoo, ampla habilidade para representar suas ações: "Sabes dar / forma à tua epopéia. Pensas elevadamente. Com / habilidade de aedo, narras teus mitos, não só os / dos argivos, mas sobretudos os teus, comoventes" (HOMERO, Od., XI, 366-369).

Se Demódoco necessitava do auxílio da Musa para evocar o passado, Ulisses guardava em si mesmo o seu arquivo de memórias. Por tal significativa diferença, na Odisséia é mais nítida a transição do aedo que compunha conforme recitava, ao rapsodo, que a princípio recitava versos aprendidos de cor, e depois ao escrevinhador que retomava os antigos temas com talento literário. Os narradores de Homero se encaixam nesse terceiro momento de transmissão da tradição épica, em que encontramos um narrador acostumado com o problema das diferentes versões de uma mesma história, em que o ver era importante para legitimar as mais diferentes recordações: "Perdi a confiança em notícias, venham / donde vierem. A vidência não me atrai" (HOMERO, Od., I, 414-415).

No lugar da evocação às Musas surge "a palavra-emblema historiê (forma jônica de historia), que impor-se-á pouco a pouco. Palavra abstrata, formada sobre o verbo historein, investigar, o termo também é ligado a idein, ver, e a oida, eu sei. 0 histôr seria, assim, a 'testemunha', 'aquele que sabe por ter visto ou sido informado' (HARTOG, 2000, p. 13). Veremos que, em Homero, o histôr perspectiva toda narrativa épica, fundamentando personagens com potencial para a rememoração testemunhal de tempos ouvidos, vistos e vividos.

\subsection{0 registro do passado em primeira pessoa: o testemunho de Ulisses}

Mesmo sendo imperioso por sempre se lembrar de casa e desejar seu retorno, Ulisses é um herói polítropos, ora agindo como orador, ora como "companheiro, amante, astucioso, cavalheiro, atleta, combatente imaginoso, poeta, marinheiro, artesão, sedutor seduzido, pai, filho" (SCHÜLER, 2010, p. 139-140). 
Com essa sedutora capacidade de fazer várias coisas ao mesmo tempo, por vezes até contraditórias, Ulisses liberta-se da tradição épica ao extrapolar a sua posição de mero ouvinte dos cantos sacros.

Para compreendermos essa libertação, temos que ter em conta que a viagem que Ulisses empreende não é só de retorno, é uma viagem de resgate do testemunho precário: "Tratar-se-ia do primeiro relato histórico? Para quem? Para nós talvez sim, mas na forma de uma cena primitiva" (HARTOG, 2000, p. 10-11). Aliás, para o autor "a historiografia grega sairá, em todos os sentidos da palavra, da epopéia. A primeira História, a de Heródoto, retomará boa parte do dispositivo da palavra épica, mesmo que em vista de seus próprios fins" (HARTOG, 2000, p. 8).

É dos gregos que parte a noção do historiador como figura subjetiva, dotado de um posicionamento enunciativo e crítico em relação aos registros do passado. Essa figuração nos parece surgir de forma efetiva na famosa cena em que Demódoco está cumprindo seu ofício sacro de recitar para a corte dos Feácios canções comemorativas de heróis e divindades, incluindo cantos sobre a guerra de Tróia, o que acabou por provocar o choro de Ulisses, o que se explica pelo fato de estar envolvido nos eventos cantados: "Silenciada a voz divina do aedo, enxugou o rosto / e retirou o pano que Ihe escondia as faces" (HOMERO, Od., VIII, 88-89).

Nesse instante, o rei Alcínoo interrompe a canção ao perceber o choro do hóspede estrangeiro que ainda não havia se identificado. É justamente nesse cenário que Ulisses passa a se sentir mais como vítima do que como vencedor de uma grande guerra, se sentindo em pleno direito de dar o seu testemunho sobre os fatos: "Não posso negar, / aflições me devastam o peito, mas meu ventre me / manda comer e beber. Ele apaga o que trago na / memória. Esqueço o que sofri" (HOMERO, Od., VII, 218-221). Ulisses cessa o banquete e o choro, e tendo aclamado o aedo da casa, faz o seguinte pedido: "Canta a beleza do cavalo, construído por Épio / guiado pelo saber de Palas Atena, engodo repleto / de guerreiros, conduzido por Odisseu contra a / acrópole inimiga, causa da queda de Tróia" (HOMERO, Od., VIII, 493-496). Tal pedido, que por si só já adianta uma série de detalhes do episódio mencionado, faz com que o herói passe por um processo de recivilização.

O pedido de Ulisses feito ao aedo nos mostra que, se o canto anterior sobre suas errâncias havia causado nele sofrimento a ponto de fazê-lo chorar, o herói agora quer sentir sensação oposta, para isso pede que 0 aedo relate 
acontecimentos de Tróia que demonstrassem sua inteligência, "o herói queria reviver as emoções sentidas no primeiro canto e desejava se expor a elas" (CAETANO, 2014 , p. 24). Procedendo assim, o herói torna-se ao longo de quatro cantos ele mesmo seu cantor, autor de "uma retrospectiva das próprias ações" (MALTA, 2017, p. 32). O próprio Ulisses passa a ser construtor de suas histórias: "Minhas palavras bateram em ouvidos / atentos: [...]" (HOMERO, Od., X, 482-483). Diante dessa abertura, entre os cantos IX a XII da Odisséia, Ulisses nos dá um prolongado testemunho de suas aventuras: "Odisseu, para quem ouve a Odisséia, pertence a uma idade longínqua; mas Odisseu, para quem ouve Demódoco, ainda vive - está, na realidade, presente à própria recitação" (MALTA, 2017, p. 24).

O envolvimento de Ulisses com o canto parece eliminar, desse modo, a distância que normalmente existia entre os feitos heróicos e os cantos em que eram lembrados e comemorados, pois seu passado é, por assim dizer, um passado recente. Nessa construção, o canto se volta, desesperadamente, para o tempo presente. O fato, assim, não é distanciado do tempo de enunciação, visto que por meio de sua visão (opsis), Ulisses proporciona ao leitor uma autópsia parcial da realidade micênica. É por isso que Aubreton vê em Homero (1968, p. 175) "o homem das precisões técnicas, e, em sua obra, um autêntico relato de viagem": "Testemunhaste-a com teus / próprios olhos? [...]. / Não te peço que me afagues com palavras de mel. / Fala-me franco o que tu mesmo viveste" (HOMERO, Od., III, 93-97).

Para cantar seu próprio passado recente, Ulisses volta-se para fora, para a realidade espacial e perceptível de suas ações, por isso não espera ver algo diferente de Ítaca ou de si mesmo. Sempre que Ulisses estava prestes a ser encantado ou assolado pela perda de memória, surge Hermes, deus mensageiro, que "Empunha o / caduceu. A um toque seu, encantos povoam olhos / sonhadores e homens emergem da vigília à luz" (HOMERO, Od., V, 46-48). Sob a guarda do deus mensageiro, o canto homérico desliza pelos modos de utilização da palavra, considerando seus efeitos benéficos e maléficos.

\subsection{0 mito como ameaça ao testemunho}

Segundo Campbell, "os reis-guerreiros da Antiguidade encaravam seu trabalho hercúleo, à feição de matadores de monstros" (2007, p. 328). No entanto, 
no retorno errante de Ulisses da guerra de Tróia, o centro não será mais o combate. Em desvantagem numérica, coube a Ulisses sempre procurar a hospitalidade das ilhas e terras desconhecidas. No registro desses insólitos contatos, Homero empregou um olhar realista na caracterização de figuras e ambientes sublimes, com deuses antropomórficos e lugares místicos.

É evidente que Homero retém informações muito precisas em topografia, bem como sobre as técnicas de navegação, mas frequentemente comete erros e confusões que provam um conhecimento indireto e também que ele mais imaginava esses lugares do que os conhecia. Contudo, Homero inseriu em sua obra, e particularmente nas narrativas de Ulisses, uma dose suficiente de realismo para oferecer aos ouvintes um estatuto minimamente verdadeiro da palavra, espécie de registro testamentário de um mundo Ocidental até então desconhecido aos gregos. ${ }^{1}$

O que deveria ser uma simples travessia de retorno transforma-se num périplo que leva dez anos para encontrar seu termo. Ulisses tentou dirigir sua esquadra de 12 navios na direção de Ítaca até que o Bóreas se levantou e o levou para "além da ilha de Kíthira até a África e a terra dos Lotófagos" (OBREGÓN, 2002, p. 86). A viagem de Ulisses parece dividir-se aqui em duas partes: uma parte real, enquanto a tripulação navega pelo Egeu, e outra irreal, fantástica, rumo a uma geografia desconhecida a extremo Ocidente. Cruzando o limiar, Ulisses navega por uma paisagem onírica povoada por formas curiosamente fluidas e ambíguas, na qual deve suportar a uma sucessão de provas, a começar pelos Lotófagos: "Quem saboreia / a doçura do loto, perde a vontade de informar, de / viajar, esquece o lar, quer permanecer, morar com / aqueles indivíduos, os lotófagos. Transtornados / pelo loto, perdem a vontade de voltar para casa. / Agarrei-os - choravam - e os arrastei aos navios" (HOMERO, Od., IX, 31-37).

$\mathrm{Na}$ aparência da hospitalidade, comunicada através do gesto de oferecer um banquete, encontramos um elemento que nos indica o contrário, pois o alimento floral do lótus retira do estrangeiro sua memória e os seus sentidos. O alimento ofertado rouba do estrangeiro a vontade de retornar e impede a própria realização do testemunho, alegoria da persuasão em detrimento da memória vivida. Logo, "a memória nos constrói e reconstrói. Somos filhos da memória" (SCHÜLER, 2008, p.

\footnotetext{
1 "Todas as Narrativas de Ulisses nada mais seriam que a retomada das lendas que celebram no dia da primavera o reinício da navegação a partir de Corcira, ponto nevrálgico do sistema coríntio" (AUBRETON, 1968, p. 175).
} 
260). Ulisses não consome a flor, por isso ele é o sujeito que conserva a memória, aquele que mantém a tradição. Seguindo as inúmeras tentações resistidas, Ulisses sobrevive às seduções do canto mágico das Sereias.

As Sereias seriam transposições míticas das aves infernais que tinham ofício de coveiros. Elas se alimentam de carne humana e tentam arrebatar a alma das vítimas por meio de cantos sedutores. Tais criaturas aparecem como cantoras tentadoras que apresentam ao viajante sua versão da guerra de Tróia, o que representa um desafio para Ulisses, por confundi-lo na construção de suas próprias lembranças. Precavidos por Circe, seus companheiros passam pelas sereias de ouvidos vedados. Só Ulisses fora amarrado ao mastro do navio, de tão curioso que estava para ouvir o que as Sereias tinham a relatar sobre fatos que ele próprio vivera e testemunhara:

[...], que nosso hino delicie de perto o teu coração. / Todos nos ouve. E a regra. Sem nos / ouvir ninguém passou aqui em nau negra. / Com nosso saber prossegue mais pleno. Do que / se passou nos campos de Tróia sabemos tudo / por divino favor, os padecimentos de troianos / e argivos, mais o ocorrido na prolífera terra (HOMERO, Od., XII, 183-195).

A Odisséia contém, portanto, uma espécie de reflexão geral sobre a função do aedo, sobre a grandeza de seu canto e suas possibilidades de construção, sem deixar de alertar-nos sobre os perigos de um relato falso. Com esse episódio, notamos que a fascinação pela revelação do passado é tão perigosa quanto o esquecimento. Querer dizer exatamente o que ocorreu pode ser tão venenoso quanto o efeito entorpecedor do lótus, provocando o esquecimento ao cantar eventos sem apurar testemunhas. Essa será a prova que Ulisses terá de suportar diante das Sereias e de todas as outras criaturas,

O cenário paradisíaco desses encontros pode ocultar monstruosidades infernais, assim como discursos verossímeis podem conter mentiras, como ocorre no caso dos Ciclopes de Homero, filhos de Posidon, em que somos apresentados a Polifemo, um canibal comedor de gente de um olho só. A descrição do interior de sua caverna confere toda naturalidade ao fantástico da cena: "Examinamos tudo. Queijos secavam em / grades. Nos curais comprimiam-se cabritos e / carneiros. [...]. Soro escorria das vasilhas, eram muitas. Ele usava tarros e gamelas na ordenha" (HOMERO, Od., IX, 218-226). Além disso, a "bosta de animal era rica na caverna [...]" (329). 
O gigante não exita em devorar dois de seus tripulantes. Ulisses, similar aos Lotófagos, oferece à criatura o vinho que trouxera para acalmar e ludibriar o mau anfitrião: "[...], meu caro / Ciclope, junta vinha ao festim de carne de heróis" (HOMERO, Od., IX, 346-347). Polifemo pede para repetir várias vezes a bebida e logo o sono the atinge em cheio: "Agarrou e bebeu. / Botou de um trago a preciosidade goela abaixo [...]" (HOMERO, Od., IX, 353-355). Em estado de sono profundo, Ulisses tem a ideia de cegar Polifemo para que, no dia seguinte, sua tripulação escapasse com menos dificuldade: "Eles levantaram / a lasca talhada de ponta ardente, firmaram-na no olho, / e eu, pressionando de cima, a girei como quem fura a / trado a trave naval" (HOMERO, Od., IX, 382-386).

Enganado e cego do único olho, o gigante se humaniza, passando a recordar, a um dos seus carneiros, episódios da sua vida diária, cenas que não poderão mais ser vistas: "Meu amado por que essa lentidão? O derradeiro hoje és tu? Preguiçoso! Não costumas a encerrar o cortejo. Na ponta da tropa, tosas no prado as florzinhas que topas" (HOMERO, Od., IX, 446-451). Ao escapar desses e outros monstros, Ulisses se mantém na rota do Sol, chegando aos rebanhos do deus Hélio. Portanto, Ulisses faz de sua embarcação um verdadeiro carro do Sol, em prol de uma navegação mais esclarecida. Na reluzente circunavegação realizada, fecha-se o ciclo do mito-aventura em que se desenha o mundo imaginário de Ulisses, universo que consiste num anel de terra cercando os mares conhecidos: o Mediterrâneo oriental e o Egeu. ${ }^{2}$

Por fim, o herói parece desempenhar um triste papel como descobridor por se voltar somente ao que seus olhos viram. Ademais, navegava imaginando no horizonte infinito a sua terra natal, mesmo após dez anos longe: "Só Ihe interessava o retorno à pátria." (HOMERO, Od., XIII, 30). Nele nada se nota do encantamento de um navegante a quem um novo mundo de sabedorias se lhe revela e espanta.

\subsection{A catábase proibida: Ulisses no mundo dos mortos}

Seguindo o Sol, Ulisses dá a volta ao mundo parando em regiões obscuras: a morada dos Cimérios, o mundo dos mortos ou "a terra dos sem-olhos" (HOMERO, Od., IX, 524-525), situada na região oposta aos rebanhos de Hélio, protegida pelos

\footnotetext{
${ }^{2}$ Era provável que na época micênica já era difundido o mito que conta que "Zeus mandava suas pombas para o leste e elas retornavam do oeste, portanto os gregos antigos sabiam que a Terra era redonda, [...]. Assim, sabiam que não cairiam da beira do mundo" (OBREGÓN, 2002, p. 25).
} 
soníferos portais da Eeia, a ilha de Circe. De todas as viagens traçadas, as paragens sombrias do Hades são as mais longas e difíceis para os humanos presos aos sentidos, seres sedentos de luz como Ulisses.

Diante da geografia percorrida por Ulisses percebe-se que há certa simetria na sequência de lugares em que aporta. No mapeamento de suas errâncias, temos com a ilha de Hélios uma simetria espacial opositiva em relação à localização do Hades, situado, por sua vez, no "terminal point of the path of night, being located near Circe's 'cosmic gate'. In other hand, Helios' own island is located at the end of the path of day, close to Calypso's island, in the western cosmic juncture. Reaching Helios signifies the end of the journey; where cannot go much further" (MARINATOS, 2001, p. 401). Na composição desse cenário cíclico, temos uma narrativa de viagem cósmica, gênero corrente no leste mediterrânico, na Babilônia e no Egito antigos.

Não diferente na Odisséia, de Circe a Calipso, a viagem de Ulisses liga extremos de um imaginário cósmico possivelmente difundido no mundo micênico. Ao aportar na morada de Circe, nascida do Sol e de uma filha do rio Oceano, descrevese mais um cenário paradisíaco iluminado pelo dia, cenário reluzente que não passa de outra cilada, pois Circe é uma feiticeira oriental que conhece drogas alucinógenas perigosas e eventualmente fatais: "Juntou a um preparado drogas fulminantes com / poderes de apagar totalmente lembranças da / pátria Ao provarem o mingau preparado por ela, / Circe os tocou com uma varinha e os prendeu / numa pocilga. De porcos tinha a cabeça, a voz, / as cerdas e o corpo. A inteligência, entretanto, / permaneceu de pé" (HOMERO, Od., X, 235-242).

Ulisses marchou para o seu castelo, sendo antes armado por Hermes, que Ihe deu uma erva mágica para reter a magia da feiticeira: "O feitiço dela não pega em ti. / O antiveneno que te passo não / deixa" (HOMERO, Od., X, 274-276). Após uma prolongada estadia, Circe aconselha Ulisses a navegar até o Oceano "onde o sol encontra sua morte", para obter previsões de sua volta: "Deverás consultar a sombra de Tirésias, o vidente / [...]" (HOMERO, Od., X, 482). É preciso admitir, nessa passagem, a explícita referência à tradição órfica da catábase, porém as forças espirituais não "são revitalizadas para uma transfiguração do mundo" (CAMPBELL, 2007, p. 35-36). Não se trata aqui de uma iniciação de autodescoberta, de "técnicas para levar a consciência individual a retirar a ênfase das vestes, [...] para atingir as camadas profundas e alcançar imperscrutáveis percepções" (CAMPBELL, 2007, p. 371). 
A catábase de Ulisses está destituída de elementos metafísicos, reduzida à meia dúzia de adivinhações. Tudo se passa como se ele simplesmente não tivesse descido ao Hades e, ao falar com os mortos, age como no mundo dos vivos: “Desejei aproximar-me / com ternura daquela que me deu a vida, abraçá-la. / Três vezes tentei estreitá-la nos braços, guiada pelo / coração. Três vezes ela me escapou. Era só imagem, / sonho" (HOMERO, Od., XI, 204-224). Após obter informações da sombra de Anticléia, sua mãe, Ulisses, como se estivesse em Ítaca, tenta abraçá-la, mas o contato não vai além das palavras.

Os mortos em Homero são, portanto, "cabeças sem forças", "seres sem nervos", iguais a sombras, metáfora da inutilidade da empresa, pois as informações colhidas nada acrescentaram aos conselhos de Circe: "Partireis só amanhã quando a Aurora pintar o céu. / Eu vos ensinarei o caminho. Assinalarei cada etapa. / Quero que a viagem transcorra sem / erros, sem imprevistos. Evitarei sofrimentos no mar e na terra" (HOMERO, Od., XII, 24-30). Urge ouvirmos, nesse momento, Tirésias, cego para os objetos banhados de luz: "Busca o mel do regresso? [...]. Um / dos celestes não te deixará escapar. Refiro-me ao / Abala-Terra. A cólera enegrece-lhe o coração. / Cegaste o filho dele. Ele o amava. Ainda assim, / com sofrimento poderás alcançar o que desejas, / se fores comedido, tu e teus companheiros" (HOMERO, Od., XI, 90-105).

A novidade de sua profecia está na indicação do remo que o herói deve levar aos homens que desconhecem o mar após seu retorno, alcançando, assim, o tão esperado descanso: "Toma, então, um bem talhado remo e ruma / a povos que desconheçam o baile das ondas sonoras / do mar, [...]" (HOMERO, Od., XI, 122124). O remo, instrumento da aventura e da morte, converte-se em símbolo da paz entre os povos, oposto à pá camponesa, presa pela disputa da terra que o cerca, metáfora do marinheiro eternamente ancorado em sua ilha: "Quero ver com estes meus olhos de Odisseu, / ainda que seja nas sombrias profundezas da terra" (HOMERO, Od., XX, 79-80).

Como um navio a andar sempre ancorado no mundo dos vivos, surge a sombra de Aquiles, saudado por Ulisses: "Não conheço homem mais sortudo, nem antes nem depois. / Vivo, nós te tributávamos honras devidas a deuses. E / agora te encontro aqui como rei dos que passaram pela / terra". A resposta amarga de Aquiles, no entanto, não se fez esperar: "Não / tentes embelezar a morte na minha presença, meu / atilado Odisseu. Preferiria como cabra de eito trabalhar / para outro, 
um pobretão, a ser rei desse povo de mortos" (HOMERO, Od., XI, 483-490). Aquiles preocupa-se apenas em ser honrado pelo canto depois de morrer no campo de batalha, o que Ihe garantiria a glória imortal firmada pelo canto divino dos aedos.

Pelo mesmo motivo, Ulisses não aceita a imortalidade oferecida por Calipso. Isso implicaria em permanecer desaparecido do mundo humano. Para Ulisses, era preferível "ser lembrado no teatro das ações humanas a viver inativo à sombra de uma deusa" (SCHÜLER, 2008, p. 245): "Pertenço aos que sofrem. Sou homem" (HOMERO, Od., VII, 211-213). Sua aventura é um retorno paranóico, complacência do mesmo: "A cabeça de Odisseu consultava a / cada instante a posição do sol. Que desaparecesse / duma vez! Só lhe interessava o retorno à pátria. / Imagine-se um lavrador impaciente após um dia / de trabalho" (HOMERO, Od., XIII, 28-32).

Viajante a contragosto, exposto ao ódio de Posidon, "Ulisses não se encontra, afinal, em busca de algum tipo de absoluto - e nem tem curiosidade com relação ao mundo" (HARTOG, 2004, p. 19). Eis a mentalidade micênica que Homero tentou contornar em suas épicas, preenchido por um gosto naturalista que nos aponta uma mentalidade micênica que tendia mais à vida terrena em detrimento da morte.

\section{Telemaquia como reconstrução do testemunho histórico: os indícios sobre o retorno de Ulisses}

Dos feitos de Ulisses na guerra de Tróia, temos o relato dos seus companheiros de guerra, Nestor e Menelau, que preservaram o herói na memória. Ou seja, "ao menos a memória iliádica de Ulisses foi preservada" (ASSUNÇÃO, 2011, p. 167-168). Antes de empreender a narrativa das aventuras de Ulisses, Homero nos apresenta, na Odisséia, uma Telemaquia em quatro cantos, em que temos o crescimento de Telêmaco, seu filho, cuja fase de maturação envolve paralelamente a evolução da reconstrução da memória do próprio pai.

Sendo irreversível o tempo, irremediáveis são as transformações. Toda a telemaquia se resume nisto: a passagem do jovem Telêmaco à idade adulta. Ele passa a tomar decisões, convoca os pretendentes, expõe-lhes seu plano de ir atrás de indícios que possam apontar a sobrevivência e o possível retorno de Ulisses à Ítaca. Longo foi o processo até Telêmaco obter tais informações. Para seu auxílio, a deusa Atena se disfarça no jovem guerreiro Mentes: "[...] irei a Ítaca para / animar Telêmaco. Quero infundir-Ihe ardor. [...]. Eu o enviarei a Esparta e à arenosa Pilos 
para saber do regresso do pai, / colher informações, ilustrar seu nome entre os povos" (HOMERO, Od., I, 87-95). Telêmaco, aquele que "vê e combate de longe" (VIDAL-NAQUET, 2002, p. 86), parte para obter informações sobre seu pai, a fim de reconstituir memórias fragmentadas.

A busca de Telêmaco não conhece a variedade de incidentes nem a intensidade dramática das viagens de seu pai. Sua busca é apenas introdutória, narrada ao sabor das circunstâncias, conotada de significações presentes. $O$ narrador sabe modular tais efeitos, erigindo um ambiente luminoso e mundano das regiões conhecidas do Egeu. Portanto, Telêmaco só viaja no mundo conhecido entre os aqueus. De Ítaca, ele ganha Pilos, onde reina o velho Nestor, e depois vai a Esparta, reinado de Menelau e Helena. Em Pilos, Telêmaco fica diante um de ancião renomado, mostrando que a viagem é, sobretudo, de busca e aprendizagem, para isso o jovem inicia a comunicação prezando por qualquer informação que tenha sido testemunhada: "Testemunhaste-a com teus / próprios olhos? Sabes de outrem se ainda navega / errante? Nasceu de mãe que o gerou para a dor? / Não te peço que me afagues com palavras de mel. / Fala-me franco o que tu mesmo viveste. Imploro. / [...]. / Não me ocultes nada. Não quero ser enganado" (HOMERO, Od., III, 92-101).

O velho Nestor ainda sente o mesmo prazer em narrar suas memórias, embora nada possam informar a Telêmaco sobre o pai: "Desde que aqui cheguei, / caro jovem, estou sem notícias. Nada sei deles" (HOMERO, Od., III, 183-184). Por isso, Nestor o envia a Menelau, que foi o último a regressar de Tróia, o que dará alguma esperança ao filho de Ulisses: "Recomendo que faças uma visita a / Menelau, que voltou, não faz muito, de uma viagem / a terras muito distantes. Ninguém esperava que / pudesse regressar de lá. Ventos o tinham arrastado / ao mar profundo. Aves não venceriam o trajeto / nem em vôo de um ano inteiro" (HOMERO, Od., III, 294-325).

Em Esparta, apesar de se depararem com a cidade em festa, ao verem e ouvirem Telêmaco a lamentar o destino de Ulisses após a guerra de Tróia, o episódio culmina em lágrimas que nem Helena e Menelau sabem conter. Para tanto, Helena, hábil anfitriã, lembra-se de deitar uma droga no vinho que oferecera ao filho de Ulisses, no intuito de acalmar os ânimos. Ao aceitá-lo, Telêmaco se expõe ao risco de perder a memória, uma vez que o vinho servido ao jovem por Helena é adulterado por meio de um alucinógeno: "A droga, lançada na cratera, tinha o poder 
de proteger / contra amarguras por um dia inteiro. Era eficaz em / pessoas entristecidas pela perda do pai ou da mãe" (HOMERO, Od., IV, 223-225).

De qualquer modo, Menelau o recebe bem, compartilhando de imediato o seu relato. O relato de Menelau, como o de Ulisses, também se atém a tudo que pôde ser captado pela sua visão humana: "Privações em / longes terras foi o preço do que recolhi em navios / por oito duros anos. Naveguei por Chipre, Fenícia, / Egito. Alcancei etíopes, sidônios, erembos. / Cheguei à Líbia, onde até cordeiros são chifrudos, / as ovelhas embarrigam três vezes ao ano, não / falta nada a ninguém, nem a proprietário nem a / pastor, há fartura de carne, de leite, de queijo sem / igual" (HOMERO, Od., IV, 81-94).

Menelau recorda a última vez em que ouviu falar de Ulisses: foi numa ilha próxima ao Egito, numa de suas errâncias forçadas pelo meu tempo. Nessa ocasião, Menelau apoderou-se ardilosamente de Proteu, o velho do mar, divindade oracular, para obter informações indispensáveis ao seu retorno, sendo avisado também da morte do irmão Agamênon e do isolamento do companheiro Ulisses em Ogígia: "A resposta do Velho não demorou: / 'O terceiro, o que ocupa o trono de Ítaca, é o filho / de Laertes. Eu o vi triste, a cara molhada de lágrimas. / Vive na gruta de Calipso. $\mathrm{O}$ sofredor está preso. / A ninfa não permite que o detento a deixe. Perdeu / tudo. Não Ihe restam companheiros nem navios para / afrontar a fúria das ondas" (HOMERO, Od., IV, 554-560).

Logo, Ulisses não é a única vítima dessa guerra, nem mesmo o único narrador dessa épica. Em sua viagem, Telêmaco colhe a versão dos fatos de testemunhas como Nestor e Menelau. Abre-se o leque, nem sempre convergente, das várias visões do passado. A voz das Musas se refrata nas vozes dos narradores e testemunhos da guerra de Tróia. Mas não esqueçamos a capacidade que a palavra tem de enganar. Helena, por exemplo, tem o cuidado de aliviar a tristeza contando histórias alegres e servindo alucinógenos. Todavia, a viagem de Telêmaco, portanto, o adverte sobre um possível futuro, fazendo não apenas afirmar a sua identidade de adulto como também restabelece a memória do pai. Desta iniciação em diante, as ações de Telêmaco já não são de quem busca, mas de quem sabe o que quer e o que fazer: preparar o terreno para a chegada artificiosa de Ulisses.

\section{A hospitalidade como testemunho compartilhado}


O código de hospitalidade foi bem conduzido por Nestor e Menelau, que respeitaram as necessidades básicas do banho, de vestes e do banquete de Telêmaco, e, principalmente, trocaram informações pessoais e públicas como forma de manter a transparência entre hóspedes e anfitriões. Como "o radical latino hospes (anfitrião), que dá origem às palavras opostas hospitalidade e hostilidade" (SILVA, 2017, p. 191), a obra traduz essa ambiguidade por meio da preocupação pela boa hospitalidade e pelo verdadeiro testemunho.

Assim observa-se na cena em que Penélope questiona um dos errantes que afirmam ter visto e hospedado Ulisses: "Amigo, permite que te ponha à prova. Quero saber / se de fato hospedaste em tua casa meu marido, / acompanhado de companheiros seus, como afirmas. I Conta-me como se vestia, qual era o seu aspecto, / que aparência tinham os homens que o seguiam" (HOMERO, Od., XIX, 213-217). A guerra de Tróia terá início, justamente, porque o acordo de hospitalidade entre aqueus e troianos é rompido, pois Páris Alexandre raptou a esposa de Menelau, seu anfitrião espartano.

O próprio Ulisses como estrangeiro representa um perigo radical para toda terra onde chega. No entanto, o episódio mais paradigmático acerca do exposto é aquele em que se instala a hospitalidade pacífica entre Ulisses e os Feáceos, em que um delicado código de hospitalidade é respeitado. Entre os Feáceos, Ulisses encontra um povo entregue não às artes da luta e da guerra, mas sim às alegrias da paz, da dança, do canto e do banquete. Ulisses é bem recebido, sua lembrança não é ameaçada por nenhum tipo de artifício; muito pelo contrário, como visto, é nessa corte que, mesmo diante de Demódoco, seu relato também é requerido: "Contei-lhe tudo com detalhes. / Quando lhe pedi ajuda para voltar à minha / terra, não me disse 'não'” (HOMERO, Od., X, 17-18).

Os Feáceos são apresentados como uma sociedade modelo, onde todos tinham direito à hospitalidade. Isso traz um risco que ilustra a ambivalência fundamental do mundo heróico face ao estrangeiro não bem-vindo: a subsequente oscilação entre um mundo de memórias salvas e em perigo. Aceitar o outro na própria intimidade é aceitar o risco que sua presença pode vir a representar para a lembrança de sua estirpe, como o destino trágico dos Feáceos bem o indica: "[...] Posidon vivia irritado conosco / por conduzirmos todos a porto seguro. Ameaçou / arrasar um dia uma das preclaras naus dos famosos / feáceos que retornasse de uma missão de resgate, [...]" (HOMERO, Od., VIII, 566-570). 
Os Feáceos amparam Ulisses em seu retorno à Ítaca. Cauteloso, o herói obtém informações o interior do palácio. Passo a passo, o rei desvenda segredos, identifica os pretendentes, descobre os sentimentos da esposa e conhece as intenções do filho. Para manter o disfarce, o herói precisa fazer um mau uso da palavra: ele irá mentir a todos a sua volta. Porém, aqui mesmo as mentiras contêm derivações realistas: Ulisses precisa manter sua identidade, preservar a memória de suas aventuras. Desse modo, a verdade desponta na mentira: "No / relato de Odisseu, fatos e invencionices se / misturavam" (HOMERO, Od., XIX, 202-204).

Como já exposto por Auerbach, o desfile das ações ocorre em "primeiro plano", isto é, em pleno presente espacial e temporal: "[Homero] só conhece o primeiro plano, só um presente uniformemente iluminado, uniformemente objetivo; [...], e a estória da cicatriz torna-se um presente independente e pleno" (AUERBACH, 2009, p. 5). Em resumo, Ulisses recupera sua própria percepção ao experimentar um dos pressupostos do retorno - a possibilidade de explorar os sinais do testemunho. O mesmo ocorre quando Penélope, pedindo que Ulisses, enquanto hóspede disfarçado, caracterize suas próprias vestes, reconhece os indícios da verdade: "Ela reconheceu os sinais. Não havia erro" (HOMERO, Od., XIX, 250).

O testemunho imerso nessa lógica dos indícios compartilhados incita a hospitalidade, tornando-se uma espécie de ética e de dom que o hóspede oferece a seu anfitrião e vice-versa. Não será assim entre Ulisses e os Lotófagos, mas assim ocorrerá entre Ulisses e os Feácios e entre o Ulisses disfarçado de mendigo e o porqueiro Eumeu e Penélope, em Ítaca: "O herói retorna para contar o que viveu e somente narrando é que retorna de vez" (COSTA, 2017, p. 184). Se as façanhas de Ulisses proclamam-no herói, é porque Homero, o grande construtor de sua história, representou suas aventuras apropriadas nas experiências do cotidiano dos grupos micênicos. Tais experiências serão apresentadas como símbolos limite da inteligibilidade da época, de um lado, e, de outro, da memorização dos feitos heróicos realizados sob a claridade do dia, aurora que metaforiza o relato testemunhado por olhos atentos ao movimento.

\section{Referências}

ARISTÓTELES. Arte Poética. Prefácio de Maria Helena da Rocha Pereira. Tradução e notas de Ana Maria Valente. Lisboa: Fundação Calouste Gulbenkian, 2004. 
ASSUNÇÃO, T. R. Infidelidades veladas: Ulisses entre Circe e Calispo na Odisseia. nuntius antiquus, Belo Horizonte, v. VII, n. 2, p. 153-176, 2011.

AUBRETON, R. Introdução a Homero. 2. ed. São Paulo: Difeu; EDUSP, 1968.

AUERBACH, Eric. Mimesis: a representação da realidade na literatura ocidental. Trad. George Bernard Sperber. São Paulo: Perspectiva, 2009[1946].

CAETANO, A. Demódoco e as lágrimas de Odisseu. nuntius antiquus, Belo Horizonte, v. X, n. 1, p. 17-30, 2014.

CAMPBELL, J. O herói de mil faces. Trad. Adail Ubirajara Sobral. SP: Pensamento, 2007.

COSTA, L. L. da. Os Lotófagos da Odisseia ou sobre o esquecimento do retorno. Caderno Pesquisa do Cdhis, v. 30, n.2, p.169-185, 2017.

FINLEY, Moses. O mundo de Ulisses. 3. ed.. Lisboa: Editorial Presença, 1988.

GRETHLEIN, J. From imperishable glory to History: the lliad and the Trojan War. In: KONSTAN, D.; RAAFLAUB, K. (Ed.). Epic and History. West Sussex: WileyBlackwell, 2010, p. 122-144.

HARTOG, F. Memória de Ulisses: narrativas sobre a fronteira na Grécia antiga. Trad. Jacynto Lins Brandão. Belo Horizonte: UFMG, 2004.

HARTOG, F. A fábrica da história: o "acontecimento" à escrita da história: as primeiras escolhas gregas. História em Revista, v. 6, p. 7-19, 2000.

HAVELOCK, E. A Revolução da Escrita na Grécia e suas Conseqüências Culturais. Trad. Ordep José Serra. São Paulo: Ed. Unesp; Rio de Janeiro: Paz e Terra, 1996.

HOMERO. Ilíada. Trad. Haroldo de Campos. São Paulo: Mandarim, 2001. v. 1 e 2.

HOMERO. Odisséia: Telemaquia. Trad. D. Schüler. Porto Alegre: L\&PM, 2010. v. 1.

HOMERO. Odisséia: Regresso. Trad. D. Schüler. Porto Alegre: L\&PM, 2008. v. 2.

HOMERO. Odisséia: Ítaca. Trad. D. Schüler. Porto Alegre: L\&PM, 2011. v. 3.

MALTA, A. Traduções em prosa da Odisseia de Homero: exemplos e problemas. nuntius antiquus, v. X, n. 1, p. 5-15, 2014.

MARINATOS, N. The Cosmic Journey of Odysseus. Numen, v. 48, n. 4, p. 381-416, 2001.

OBREGÓN, M. Além dos limites do oceano. Trad. Miriam Groeger. Rio de Janeiro: Ediouro, 2002. 
$\mathbb{B}_{\text {गissei }} \mathcal{A}$

SCHÜLER, D. Odisséia, a epopéia das Auroras (1). In: HOMERO. Odisséia. Trad. D. Schüler. Porto Alegre: L\&PM, 2010. p. 139-154.

SCHÜLER, D. Odisséia, a epopéia das Auroras (2). In: HOMERO. Odisséia. Trad. D. Schüler. Porto Alegre: L\&PM, 2008. p. 242-278.

SCHUTZER, L. de C. A descoberta da morte e o mundo Homérico. Revista de História, v. 12, n. 26, p. 379-402, 1956.

SILVA, G. J. (Org.). A ideia de história na Antiguidade Clássica. São Paulo: Alameda, 2017.

VIDAL-NAQUET, Pierre. O Mundo de Homero. Trad. Jonatas Batista Neto. São Paulo: Companhia das Letras, 2002. 